\title{
Dibalik Alasan Nabi Muhammad Dijadikan Wasilah dalam Berdoa: Kajian Lingusitik Kognitif
}

Nailah Sa'diyatul Fitriah

Magister of Linguistics, Faculty of Cultural Sciences,

Universitas Gadjah Mada, Yogyakarta, Indonesia

\section{Article Info}

Article history:

Submitted Feb 13, 2020

Revised Feb 21, 2020

Accepted Aug 07, 2020

Published Nov 02, 2020

\section{Keywords:}

Cognitive Linguistics

Prototype

Idealized Cognitive Model (ICM)

Prophet Muhammad

Prayers

\begin{abstract}
According to Cognitive Linguistic theory, humans think in three ways. Two of them are thinking prototypically and ideally. One of the example of these ways can be seen from how Moslems use the blessings of the Prophet Muhammad as a bridge in granting their dua. Most of Moslems assume that the Prophet Muhammad could intercede for prayer. Based on this interesting issue, this article aims to find out the prototypes of PROPHET MUHAMMAD idealized by Moslems in translation of Maulid Simtudduror book.This book contains of a range of praise, history, and prayers offered to the Prophet Muhammad as a wasilah for their prayers. By using Rosch et al (1991) prototype model analysis method and an ideal cognitive model based on the stereotype model of society initiated by Lakoff (1987), it can be concluded that the prototype of PROPHET MUHAMMAD idealized by Islam and Moslems show some features of the Prophet Muhammad in several MODELS bringing blessings for all human beings in this world. Thus, most of Moslems believe that PROPHET MUHAMMAD can be a wayin helping them to grant their prayers.
\end{abstract}

\section{Corresponding Author:}

\section{Nailah Sa'diyatul Fitriah}

Magister of Linguistics, Faculty of Cultural Sciences,

Bulaksumur, Yogyakarta, Indonesia.

Email: nailah.s@mail.ugm.ac.id

\section{PENDAHULUAN}

Bagi para pemeluk agama Islam, Nabi Muhammad menjadi sosok terpenting dalam kehidupan. Nabi Muhammad merupakan insan mulia yang patut menjadi kekasih Allah. Beliau diutus tidak hanya untuk umat manusia saja, tetapi juga untuk makhluk-makhluk lain di seluruh alam yang mencakup hewan, tumbuhan, bahkan para malaikat, dan jin. Kebenaran ini disampaikan oleh Allah dalam QS. Al-A'raf: 158 sehingga Nab Muhammad disebut sebagai rahmat seluruh alam (Rahmatan lil 'aalamiin). Dalam ayat tersebut dijelaskan juga bahwa Nabi Muhammad merupakan manusia pilihan yang diutamakan Allah. Dia dijadikan Allah sebagai manusia yang memiliki kedudukan tertinggi di sisiNya (QS. Al-Isra': 79). Selain itu, keistimewaan Nabi Muhammad di sisi Allah adalah dijadikannya sebagai satu-satunya Nabi yang namanya bersanding dengan nama Allah di Arsy-singgasana Allah. Andaikata seluruh keutamaan Nabi Muhammad SAW digambarkan pada artikel ini, maka ribuan halaman tidak akan cukup untuk menjelaskannya. Dari beberapa uraian tentang keistimewaan Nabi Muhammad di atas dapat dikatakan bahwa singkatnya, keberadaan Nabi Muhammad SAW memberikan 
keberkahan bagi seluruh alam, salah satunya umat manusia, berkat rasa cinta Allah yang tinggi kepadanya.

Bentuk Allah memuliakan Nabi Muhammad tidak hanya terihat dari keistimewaankeistimewaan yang diberikan Allah kepadaNya, tetapi juga "fasilitas" VVIP yang Allah berikan kepada umat Nabi Muhammad. Misalnya, Allah tidak akan menolak doa umat Nabi Muhammad jika mereka berdoa dengan menggunakan wasilah nama Nabi Muhammad. Bentuk wasilah atau perantara itu bermacam-macam, salah satunya bacaan salawat. Sebagaimana yang dikatakan oleh sahabat Ali bin Abi Tholib bahwa semua doa itu terhalang, sampai dibacakan salawat untuk Nabi Muhammad SAW, sebagaimana yang disampaikan oleh Baits (2011) dalam laman konsultasisyariat.com. Maka tidak mengherankan lagi jika pada praktik ibadah kesehariannya hampir seluruh umat Islam sebelum memanjatkan doa-doa selalu diawali dengan bacaan hamdalah dan salawat untuk Nabi Muhammad SAW, sebagaimanya yang sering ditemukan dalam doa-doa setelah shalat ataupun dalam pelaksanaan doa-doa pada praktik keagamaan yang lain.

Jika melihat pada fenoman nyata yang sangat mudah ditemukan dalam kegiatan sehari-hari, masyarakat mungkin berpikir bagaimana bisa seorang Nabi, yang notabene juga termasuk golongan manusia, dapat dijadikan perantara terkabulnya doa para umat Islam. Berdoa yang hakikatnya merupakan kegiatan sakral di mana seorang hamba harus benar-benar khusyu' dan menghamba kepada Rabbnya demi terkabulnya keinginan mereka, maka dengan berkah Nabi Muhammad sang Maha Pemberi tersebut akan segera mengabulkan doa baik hambaNya. Pertanyaan semacam ini wajar saja, karena berdasarkan prinsip kategorisasi, Rosch (1978: 2) menejelaskan bahwa adanya kategorisasi yang dibuat oleh manusia merupakan hasil dari adanya cara pandang tertentu terhdap dunia memberikan struktur-struktur informasi yang tersedia dan tersemat pada suatu hal yang dia pandang. Dalam hal ini, yang dimaksudkan adalah struktur informasi dan label-label alamiah yang tersemat pada diri Nabi Muhammad, bukan struktur informasi yang bersifat arbitrer atribut-atribut yang tidak dapat diprediksi. Pernyataan Rosch tersebut ternyata juga dapat dibuktikan dari segi pandang keagamaan bahwa atribut alamiah yang melekat pada diri Nabi Muhammad dapat dijadikan sebagai wasilah terkabulnya doa seorang hamba. Atribut-atribut tersebut telah dijelaskan dalam kitabkitab agama Islam, terutama yang membahas tentang keutamaan Nabi Muhammad, seperti kitab Syamailur Rosul, Simtudduror, Mulid Diba'iy, dan lain-lain. Kitab-kitab tersebut menjabarkan keutamaan Nabi Muhammad berdasarkan persepektif yang berbeda. Kitab Syamailur Rosul mendeskripsikan keutamaan Nabi Muhammad berdasarkan ciri fisik, sifat, dan sikap sehari-hari Nabi Muhammad. Sedangkan kitab Simtudduror dan Mulid Diba'iy membahas kemuliaan dan keutamaan Nabi Muhammad berdasarkan sejarah dan sifat-sifat muliaNya. Dari kitab-kitab tersebutlah masyarakat dapat mengetahui atribut apa saja yang dapat mengindikasikan Nabi Muhammad dapat dijadikan wasilah dalam berdoa.

Penjelasan tentang keutamaan Nabi Muhammad SAW di dalam kitab-kitab di atas sangat jelas dalam membeberkan bukti-bukti kemuliaan Nabi Muhammad sehingga pantas dijadikan wasilah terkabulnya doa umatNya. Sayangnya, hingga saat ini dapat dikatakan masih belum ada penelitian ilmiah yang menjelaskan alasan mengapa Nabi Muhammad dijadikan wasilah dalam berdoa, terutama jika dibuktkan melalui kebahasaan, misalnya wacana doa. Apabila ditelusuri lebih dalam dan melihat manfaatnya, kajian tersebut dapat 
menjadi penelitian kebahasaan yang sangat menarik dan futuristik. Selain sangat kurangnya penelitian-penelitian terdahulu yang melakukan penelitian pada ranah Model Kognitif Ideal atau yang sering disebut dengan ICM, penelitian kebahasaan yang menunjukkan fenomena keagamaanpun juga langka. Hal ini terbukti dari ditemukannya dua artikel hasil penelitian yang menggunakan ICM sebagai perangkat analisisnya. Pendekatan ICM digunakan untuk mengetahui hubungan dosa dan proporsi ketuhanan oleh Peels (2011) serta penelitian tentang hubungan alam dan Tuhan yang dikaji oleh Abdullah dan Hashim (2016).

Dalam Scottish Journal of Theology Ltd yang berjudul Sin and Human Cognition of God, Peels (2011) menyatakan bahwa Linguistik Kognitif dapat dijadikan alat analisis untuk mengetahui konsep ideal bagaimana dosa yang diperbuat manusia mempengaruhi pengetahuan proposisi ketuhanan seseorang. Disimpulkan bahwa dosa-dosa yang dilakukan manusia menghilangkan konsep ideal ketuhanan pada diri seorang hamba. Observasi yang dilakukan oleh Abdullah dan Hashim (2016) menyebutkan bahwa konsep ALAM dalam perspektif masyarakat Melayu melibatkan relativitas bahasa dalam mengungkapkan makna serta konsep ALAM itu sendiri. Kedua hal tersebut dipengaruhi oleh konsep asli dalam ALAM dalam bahasa Arab dan pandangan Islam. Hasilnya, konsep ALAM yang dimiliki oleh masyarakat Melayu berbeda dengan NATURE dalam pandangan masyarakat berbahasa Inggris. Konsep ALAM yang dijabarkan masyarakat Melayu meliputi dua konsep pokok, yaitu ALAM sebagai ALAM SEMSTA, ALAM sebagai DUNIA, Sedangkan NATURE, yaitu AlAM sebagai ALAM itu sendiri, ALAM sebagai LINGKUNGAN, ALAM sebagai KERAJAAN, dan ALAM sebagai RUANG TEMPORAL, Kedua penelitian di atas enunjukkan adanya hubungan antara manusia dan Tuhannya dari sisi yang berbeda, yaitu dari perbuatan manusia dan segala sesuatu yang diciptakan. Kedua penelitian di atas menggunakan ICM sebagai metode analisis untuk mengetahui prototipe suatu hal yang berhubungan dengan Pencipta dan yang diciptakan. Apabila ditarik garis, maka akan membentuk garis horizontal antara makhluk dan Tuhan. Tulisan ini mencoba memberikan nuansa baru yang mencoba menggunakan ICM sebagai pendekatan analisis hubungan manusia dengan Tuhannya yang dipengaruhi oleh Manusia lain, yaitu mencoba menguaraikan mengapa Nabi Muhammad dijadikan wasilah dalam berdoa. Jawaban dari pertanyaan tersebut dapat dimungkinkan dapat diuraikan menggunakan pendekatan Linguistik Kognitif-Idealised Cognitive Models (ICM) diasumsikan dapat menjawab fakta keagamaan ini dengan menggunakan konsep dasar prototipe dan atribut.

Ulasan di atas menunjukkan minimnya referensi penelitian model kognitif ideal pada ranah agama. Sedangkan objek penelitin di bidang ini sangat melimpah. Oleh karena itu, artikel ini mencoba untuk mengisi celah tersebut dengan menggunakan objek kajian prototipe Nabi Muhammad SAW dalam kitab terjemahan Simtudduror. Penelitian ini bertujuan untuk mengetahui: (1) prototipe NABI MUHAMMAD di dalam terjemahan kitab Maulid Simtudduror; (2) Model kognitif ideal NABI MUHAMMAD di dalam kitab terjemahan Maulid Simtudduror; dan (3) alasan Nabi Muhammad dijadikan wasilah dalam berdoa. Dengan menggunakan objek material berupa kitab terjemahan Maulid Simtudduror akan diketahui keistimewaan Nabi Muhammad serta bagaimana agama Islam dan umatNya mengidealkan sosok Nabi Muhammad sehingga dapat dijadikan wasilah terkabulnya doa. 
Berdasarkan teori model kognitif ideal, manusia berpikir dengan tiga cara, yaitu: (1) prototipikal - pola berpikir secara prominent, mengutamakan yang sentral, terpenting, terbanyak, dan dominan; (2) Radial - berpikir secara prototipe dengan periferal; dan (3) ideal - manusia berpikir berdasarkan kesepakatan ideal atas konsep atau kategori tertentu. Dari ketiga cara berpikir tersebut, di dalam artikel ini akan diulas cara berpikir manusia secara ideal, yang dilihat dari bagaimana kaum muslim mengidealkan NABI MUHAMMAD SAW berdasarkan prototipe-prototipe di dalam kitab terjemahan Simtudduror. Untuk mengetahui prototipe dan model kognitif ideal NABI MUHAMMAD, teori utama yang digunakan adalah teori prototipe dan model kognitif ideal (ICM) oleh Eleanor Rosch (1991) dan Lakoff (1987).

Teori prototipe ini dapat diaplikasikan hampir pada seluruh fenomena kebahasaan di masyarakat (Arimi, 2015: 107). Misalnya, ketika seorang muslim berdoa mereka menunjukkan unsur yang mengedepankan kasus kategori tertentu. Berdoa dengan diawali bacaan hamdalah, dilanjutkan dengan salawat menunjukkan konsep tersendiri tentang dua bacaan tersebut. Bacaan salawat, yang diasosiasikan kepada NABI MUHAMMAD, memiliki konsep yang dinyatakan dengan prototipe-prototipe tertentu. Seperti apakah sosok Nabi Muhammad yang diidealkan oleh para orang muslim? Bagaimana prototipeprototipe sesuatu atau seseorang dapat dijadikan wasilah dalam berdoa? Jawaban dari dua pertanyaan tersebut berupa prototipe-prototipe NABI MUHAMMAD yang diidealkan. Dalam bidang Linguistik Kognitif disebut idealized cognitive models (ICM) atau model kognitif ideal.

Sebelum membahas teori Model Kognitif Ideal, harus diketahui terlebih dahulu teori prototipe. Evans dan Green (2006: 255) membagi prototipe menjadi dua prinsip, yaitu: (1) prinsip ekonomi kognitif - seperti manusia yang berusaha untuk mendapat informasi sebanyak mungkin tentang lingkungannya dengan meminilamisir usaha mencari secara kognitif dan berdasar pada sumber-sumber tertentu; (2) prinsip struktur memandang dunia. Dunia di sekitar memiliki struktur korelasi. Prinsip ini menyatakan bahwa manusia bergantung pada struktur korelasi dengan tujuan untuk membentuk dan menyusun kategori.

Selain itu, Rosch dkk. (1976) menyebutkan bahwa tingkatan mendasar dari kemampuan terbaik manusia untuk mendaftar kategori-kategori adalah dengan menggunakan atribut-atribut yang melekat pada benda yang hendak didefinisikan. Model penulisan prototipe ini menggunakan tabel-tabel yang berisi daftar karakteristik menonjol dari benda yang dikategorikan. Prototipe yang tercermin dalam model atribut ini berupa kategori-kategori pada level dasar, yang ditunjukkan dengan satu atau dua atribut-atribut spesifik atau dapat juga ditambahkan dengan kategori-kategori subordinat.

Prototipe-protipe yang digambarakan dengan model atribut tersebut memberikan informasi untuk menentukan model kognitif idelanya. Model kognitif ideal (ICM) yang dicetuskan oleh Lakoff (1987) merupakam perkembangan dari teori yang Rosch dkk. Evans dan Green (2006: 270) menjelaskan bahwa teori Lakoff mengarah pada sebuah proses kognitif seperti mengkategorisasikan sesuatu beserta alasannya. Model Kognitif Ideal yang dicetuskan oleh Lakoff (1987), yang cocok digunakan di dalam artikel ini adalah model typicality effects due to metonymy atau disebut dengan ICM metonimi. Evans dan Green (2006: 273) memberikan contoh stereotipe seseorang atau sesuatu berdasarkan budaya tertentu. Model ICM metonimi ini dianggap cocok digunakan di dalam artikel ini 
karena objek kajian di sini adalah NABI MUHAMMAD yang diidealkan oleh umat Islam seperti yang terurai di dalam kitab terjemahan Simtudduror.

Lebih spesifiknya, konsep NABI MUHAMMAD yang diidealkan oleh umat Islam akan dinyatakan dengan menggunakan dua perangkat model analisis ICM, yaitu (1) stereotipe masyarakat - ICM yang muncul karena adanya kesepakatan dalam diskusi publik berdasarkan stereotipe budaya yang berlaku di dalam lingkungan masyarakat tersebut (Evans dan Green, 2006: 273). Dua teori utama di atas diharapkan dapat memberikan pemahaman tentang bagaimana Nabi Muhammad diidealkan oleh umat Islam sebagai wasilah dalam berdoa.

\section{TEORI DAN METODOLOGI}

Sumber data yang digunakan di dalam artikel ini adalah terjemahan kitab Simtudduror dan yang menjadi data utama di dalamnya adalah satuan kebahasaan yang menunjukkan prototipe-prototipe NABI MUHAMMAD. Berdasarkan data tersebut, metode yang digunakan terbagi dalam tiga tahapan,yaitu:

\section{Metode Penyediaan Data}

Metode simak bebas libat cakap (SBLC) digunakan untuk medapatkan sumber data, yaitu sebuah metode dengan mengadakan observasi terhadap objek penelitian tanpa terlibat di dalam suatu percakapan tertentu (Sudaryanto, 1988: 3). Metode ini cocok digunakan dalam penelitian ini yang menjadikan kitab keagamaan sebagai sumber datanya. Peneliti cukup menyimak data-data mentah kemudian memilah satuan kebahasaan yang menggambarkan prottotipe NABI MUHAMMAD untuk dimasukkan ke dalam kartu data.

\section{Metode Analisis Data}

Metode padan merupakan cara analisis data penelitian dengan menggunakan alat penentu di luar bahasa (Sudaryanto, 2015: 15). Sedangkan teknik yang digunakan di dalam metode ini adalah teknik padan referensial, metode analisis yang indikator analisisnya badalah referen yang ada, yaitu sosok yang dijadikan acuan (Sudaryanto, 2015: 26). Referen analisis di dalam analisis ini adalah NABI MUHAMMAD dilihat dari perspektif umat Islam di dalam kitab terjemahan Simtudduror. Kemudian data-data tersebut dianalisis menggunakan model prototipe atributif Rosch, dkk (1991) dan model kognitif ideal NABI MUHAMMAD berdasarkan model stereotipe masyarakat yang digagas oleh Lakoff (1987).

\section{Metode Penyajian Hasil Analisis}

Metode penyajian hasil analisis metabahasa adalah cara menyajikan hasil analisis dalam bentuk narasi, sehingga jawaban dari rumusan masalah pada penelitian ini dapat dijabarkan dengan baik (Arimi, 2009: 12). Ditunjang dengan adanya tabel-tabel yang memberikan gambaran singkat tentang prototipe-prototipe NABI MUHAMMAD dapat dipermudah dengan metode semiotik, yaitu cara penyajian hasil analisis dengan menggunakan simbol berupa tabel, grafik atau diagram (Arimi, 2009: 12). Bentuk simbol yang digunakan pada penelitian ini adalah tabel dan diagram. tabel tersebut digunakan 
untuk menyajikan daftar prototipe NABI MUHAMMAD yang diidealkan oleh masyarakat muslim dalam kitab terjemahan Maulid Simtudduror. Sedangkan tanda berupa diagram digunakan untuk mempermudah pembaca mengetahui secara ringkas hubungan prototipe dan model kognitif ideal.

\section{HASIL DAN PEMBAHASAN}

Berdasarkan teori prototipe dan model kognitif ideal yang telah disampaikan di atas dapat digunakan untuk menjawab rumusan masalah di atas. Sehingga dapat diketahui prototipe NABI MUHAMMAD yang digambarkan di dalam kitab terjemahan Simtudduror sehingga sosok NABI MUHAMMAD dapat dijadikan perantara terkabulnya doa umat Islam.

\section{Prototipe NABI MUHAMMAD dalam Terjemahan kitab Mulid Simtudduror}

Seperti yang telah dijelaskan di atas, beberapa prototipe NABI MUHAMMAD digambarkan dengan model atributif yang dicetuskan oleh Rosch (1991) dalam tabel berikut yang berhasil dihimpun dari terjemahan kitab Simtudduror.

Tabel 1. Prototipe Atributif Nabi Muhammad

\begin{tabular}{l}
\multicolumn{1}{c}{ NABI MUHAMMAD } \\
Makhluk pemuka, penutup, \\
Hamba yang didekatkan, \\
insan pilihan, \\
hamba terkasih
\end{tabular}

(Simtudduror, pp. 3)
Makhluk pembawa rahmat Tuhan, (Simtudduror, pp. 4)

Makhluk pembawa kebaikan, mempermudah yang sulit, Makhluk tertinggi dan terluas kedudukannya, Hamba paling jujur, menyampaikan kebenaran, Manusia paling baik dan paling benar

(Simtudduror, pp. 5)
Seseorang yang amat penyantun dan penyayang, (Simtudduror, pp. 19)

Semulia-mulia insan, tempat seluruh makhluk memperoleh kemuliaan, kehadirannya mengiringi rahasia keutamaan yang tersebar merata di seluruh alam semesta, insan yang tersayang manusia pembawa kebahagiaan yang merasuk qalbu, kekasih Allah, pembawa anugerah bagi seluruh manusia

\section{NABI MUHAMMAD}

Sempurnanya kewajiban penghambaan kepada Allah, penyandang segala sifat sempurna, bersungguhsungguh dalam berbakti kepada Ilahi, menghadapkan diri kepada Allah degan sebaik-baik dan sesempurna cara, shalawat rahmat mengukuhkan jalinan ikatan pribadinya bagi si pembaca yang menyentuh nur kecintaan dan kerinduan padanya, sumber dari inayah Allah kepada hambaNya.

(Simtudduror, pp. 26)

Selalu tanggap memenuhi panggilan si miskin, ayah penuh kasih sayang untuk si yatim-piatu, rendah hatinya, kuat wibawanya

\section{(Simtudduror, pp. 97)}

Ucapan dan tidakannya teratur rapi, bentuk tubuhnya sempurna, adil dan dermawan, bila berjalan seakan-akan turun dari ketinggian, bagai pusaka tersimpan rapi dalam wadah kokoh tertutup rapat, tidak ada anak kunci mampu membuka sifat-sifatnya, membuat takjub akal dan pikiran 
Insan pilhan, yang benar dan dibenarkan,

Manusia paling manis dan paing benar tutr katanya, Orang yang paling utama yang mewujudkan ketaqwaan,

Pemilik akhlak dermawan dan setia

(Simtudduror, pp. 6)

Seorang Rosul, wasilah kepada Allah, pemberi syafa'at

(Simtudduror, pp. 11)

Manusia dengan

kedudukan terhormat di sisi Allah, seorang Nabi mulia dengan derajat yang tinggi di sisi Allah

(Simtudduror, pp. 108)

Nabi dengan semua cinta Allah tertuju kepadaNya, idaman Allah, semuliamulianya wasilah (peramtara) di sisi Allah, penghulu segenap Rasul, seorang hamba dengan ucapan yang selalu benar, tulusterpercaya, junjungan umat Islam yang risalahNya melipiti seluruh jagat raya, penyimpan amanat Allah, pemegang rahasia Allah, pengibar panji dakwah Allah.

(Simtudduror, pp. 107)

Memiliki kedudukan tertinggi di sisi Allah sampai melampaui ketujuh lapis langit yang diliputi belaian karunia lembut penuh keakraban yang datang dari hadirat Ilahi, dimuliakan dengan
(Simtudduror, pp. 20)

Pribadinya mewangikan tiap majelis dan pertemuan, pusat perpaduan, kesempurnaan tiada banding dalam fisik dan perilakunya, mendapat kekhusususan termulia, perangai manusia terpuji hanya bersumber dai dirinya, insan terbaik di antaramereka semua, insan tercinta, menjulang tinggi pekerti indah, seseorang dengan kehormatan dan penghormatan serta budi pekertinya yang amat luhur.

\section{(Simtudduror, pp. 98)}

Hamba Allah yang benar dalam ucapan dan perbuatannya, menyampaikan atas nama Allah, utusan Allah untuk seluruh penghuni alam, pembawa berita gembira, perantara datangnya hidayah Allah, pelita, penerang.

(Simtudduror, pp. 25)

Seseorang dengan akal yang dapat mencapai arti dzat yang tiada satupun mungkin menyamai atau menyerupainya

(Simtudduror, pp. 27)

Manusia, jin, dan makhluk manapun tidak mempu menguraikan hakikatnya, lidah pun tidak mampu mengungkapkan makna halus yang tersembunyi padanya, makhluk yang dikhususkan oleh Allah, Nabi yang menerima anugerah agung berlimpah berdatangan dari hadiratAllah Yang Maha Esa. (Simtudduror, pp. 83)

Nur (cahaya Nabi Muhammad) telah diciptakan sebelum sesuatu yang lain, yang pertama di antara para Nabi, termulia di antara mereka semua.

(Simtudduror, pp. 40)

Ayahnya bijak dan
(Simtudduror, pp. 92)

Inti kekhususan dengan

keutamaan dan

penghormatan, tidak dapat

disamai wujud manapun bentuk fisik dan perilakunya, rahasia hikmah Allah yang tersembunyi dalam keindahan tubuh dan kesempurnaan akhlaqnya tidak dapat diselami, makhluk yang dijaga Allah sejak zaman terdahulu, tabiat dan akhlanya membentuk tabiat dan akhlaq luhur.

\section{(Simtudduror, pp. 90)}

Keluarga dan sahabatnya mencapai puncak derajat yang tinggi karena dekat kepadanya, kemuliaan sejati, shalawat dan salam terusmenerus tiada henti adalah bentuk kecintaan kepadanya. (Simtudduror, pp. 27)

Sempurna sifat-sifat keluhurannya, sifat keluhurannya tidak dapat diuraikan sampai zaman berakhir

(Simtudduror, pp. 96)

Hamba yang sempurna dan dikasihi, dengan perilaku terluhur di anatara semua perilaku, insan tercinta, nurnya yang pertama kali diciptakan, makhluk pertama yang muncul di alam semesta, wahyu yang diberikan Allah kepadanya tidak pernah didustakan oleh para Rasul lain.

(Simtudduror, pp. 39 \& 82)

Mutiara amat berharga, pertolongan Allah selalu mendampinginya, dikandunh oleh ibunya di bawah pengawasan Allah. (Simtudduror, pp. 41) Memiliki kehormatan yang dikhususkan oleh Allah , 
berbagai anugerah besar yang melimpah sebagai seindah-indah pemberian dan memanggilnya dengan semulia-mulia salam.

(Simtudduror, pp. 81) berwibawa. ibunya mulia, yang selalu merasa aman dan tenteram. meski di tengah apa saja yang menggelisahkan.

(Simtudduror, pp. 41)
kebaikanNya selalu

terlimpah, karuniaNya selalu tercurah beserta bukti-bukti kuasaNya yang gemilang dalam peristiwa Mi'raj

(Simtudduror, pp. 80)

Prototipe-protitipe di atas menunjukkan bentuk kategori bergradasi yang menunjukkan jumlah anggota kategori yang lebih sentral dari anggota kategori yang lainnya. Sebagaimana yang diungkapkan oleh Rosch (1991) bahwa prototipe merupakan "the most central member of a category." Bentuk gradasi tersebut diperoleh dengan mendaftar prototipe-prototipe yang sering muncul dalam mengonsepkan NABI MUHAMMAD di dalam Kitab terjemahan Simtudduror. Dari prototipe-prototipe tersebut dihitung jumlah frekuensi kemunculannya. yang diuraikan pada tabel di bawah ini.

Tabel 2. Frekuensi Prototipe Atributif Nabi Muhammad

\begin{tabular}{|c|c|c|c|}
\hline Prototipe & $\begin{array}{l}\text { Jumlah } \\
\text { (n) }\end{array}$ & Prototipe & $\begin{array}{c}\text { Jumlah } \\
\text { (n) }\end{array}$ \\
\hline Insan dengan kedudukan tertinggi & $\mathrm{n}=6$ & Insan pembawa berkah & $\mathrm{n}=2$ \\
\hline Insan paling sempurna & $\mathrm{n}=9$ & Insan paling dekat dengan Tuhan & $\mathrm{n}=1$ \\
\hline Insan paling utama & $\mathrm{n}=21$ & Insan pembawa rahmat Tuhan & $\mathrm{n}=1$ \\
\hline Insan pembawa keberuntungan & $\mathrm{n}=1$ & $\begin{array}{l}\text { Insan dengan kesempurnaan akal } \\
\text { yang tidak tertandingi }\end{array}$ & $\mathrm{n}=1$ \\
\hline Insan pembawa kebahagiaan & $\mathrm{n}=5$ & Insan pilihan & $\mathrm{n}=2$ \\
\hline Kekasih Allah & $\mathrm{n}=7$ & Pemipin paling sempurana & $\mathrm{n}=3$ \\
\hline $\begin{array}{l}\text { Insan dengan keindahan fisik } \\
\text { paling sempurna }\end{array}$ & $\mathrm{n}=6$ & Insan paling mulia & $\mathrm{n}=10$ \\
\hline Insan pelindung & $\mathrm{n}=1$ & Insan penyantun dan penyayang & $\mathrm{n}=4$ \\
\hline Insan pembawa kebaikan & $\mathrm{n}=2$ & Insan pembawa kemudahan & $\mathrm{n}=1$ \\
\hline Insan paling benar & $\mathrm{n}=4$ & Insan paling suci & $\mathrm{n}=1$ \\
\hline Insan yang dermawan dan setia & $\mathrm{n}=1$ & Insan penolong & $\mathrm{n}=6$ \\
\hline
\end{tabular}

Tabel di atas menunjukkan frekuensi prototipe atributif NABI MUHAMMAD dengan jumlah yang bervariasi. Informasi tersebut memberikan gambaran gradasi prototipe yang disajikan dalam delapan prototipe yang disajikan dari yang paling utama, yaitu: (1) insan paling utama; (2) insan paling mulia; (3) insan paling sempurna; (4) kekasih Allah; (5) insan dengan kedudukan tertinggi di sisi Allah; (6) insan dengan keindahan fisik paling sempurna; (7) insan sebagai penolong terbaik; dan (8) pembawa kebahagiaan bagi umat manusia. Delapan prototipe yang disusun berdasarkan frekuensi terbanyak tersebut menggambarkan prototipe sentral NABI MUHAMMAD yang disepakati oleh umat Islam. Kedelapan prototipe atributif NABI MUHAMMAD di atas kemudian akan diformulasikan dalam model kognitif ideal untuk mengetahui bagaimana umat Islam megidealkan sosok NABI MUHAMMAD yang dipercaya sebagai wasilah terkabulnya doa.

\section{Model kognitif ideal NABI MUHAMMAD di dalam kitab Maulid Simtudduror}

Kemampuan seseorang atau kelompok masyarakat tertentu untuk membentuk kategori-kategori dari item-item yang ingin dikonsepkan tergantung dari pengetahuanpengetahuan yang telah ada sebelumnya di dalam kognisi mereka. Pengetahuan tersebut berhubungan dengan nilai-nilai sentimentil yang melekat pada berbagai variasi entittas, bersamaan dengan pengetahuan tentang entitas tersebut (Evans dan Green, 2006: 270). 
Untuk mengetahui bagaiaman pengetahuan-pengetahuan yang mendahului umat Islam terhadap entitas NABI MUHAMMAD yang diidealkan dapat dirumuskan dalam bentuk model kognitif ideal (ICM) stereotipe masyarakat. Model tersebut diformulasikan berdasarkan gradasi prototipe NABI MUHAMMAD di atas sebagai berikut.

\subsection{Model Pengutamaan}

Makhluk paling utama di antara yang dikasihi Allah, memiliki mukjizat menakjubkan sebagai pendukung risalahnya yang dihususkan baginya di antara semua makhlukNya, Nur (cahaya Nabi Muhammad) telah diciptakan sebelum sesuatu yang lain, yang pertama di antara para Nabi, penghulu segenap Rasul, makhluk yang dikhususkan oleh Allah, nurnya yang pertama kali diciptakan, makhluk pertama yang muncul di alam semesta, rahamat khusus, pemuka seluruh penghuni langit dan bumi, hamba Allah yang dipenuhi sepenuhnya, dikhususkan dengan sebesar kakhsusan dari Allah, tidak sama dengan manusia biasa, utama di antara manusia seluruhnya, orang yang paling utama yang mewujudkan ketaqwaan, keutamannya merata di mana-mana, inti kekhususan dengan keutamaan dan penghormatan, tidak dapat disamai wujud manapun bentuk fisik dan perilakunya, dan kehadirannya mengiringi rahasia keutamaan yang tersebar merata di seluruh alam semesta.

\subsection{Model Kemuliaan}

Makhluk termulia di antara penghuni bumi dan langit seluruhnya, dimuliakan dengan berbagai anugerah besar yang melimpah sebagai seindah-indah pemberian dan memanggilnya dengan semulia-mulia salam, termulia di antara mereka semua, seorang Nabi mulia, kemuliaan sejati, seorang termulia di antara makhluk-makhlukNya, semuliamulia insan, dan tempat seluruh makhluk memperoleh kemuliaan.

\subsection{Model Kesempurnaan}

Rasul yang tumbuh dengan sifat-sifat paling sempurna, keluhuran pribadinya tampak sempurna sejak usianya yang amat muda, Sempurna sifat-sifat keluhurannya, sifat keluhurannya tidak dapat diuraikan sampai zaman berakhir, kesempurnaan tiada banding dalam fisik dan perilakunya, memiliki keluhuran dan kesempurnaan yang melampaui segala yang bisa dicapai pengetahuan manapun juga, sempurnanya kewajiban penghambaan kepada Allah, penyandang segala sifat sempurna, bersungguh-sungguh dalam berbakti kepada Ilahi, dan menghadapkan diri kepada Allah degan sebaik-baik dan sesempurna cara.

\subsection{Model Kekasih}

Nabi dengan semua cinta Allah tertuju kepadaNya, idaman Allah, semulia-mulianya wasilah (peramtara) di sisi Allah, hamba yang sempurna dan dikasihi, insan tercinta, hamba terkasih, dan kekasih Allah.

\subsection{Model Kedudukan Tertinggi}

Tingginya kedudukannya di sisi Allah, memiliki kedudukan tertinggi di sisi Allah sampai melampaui ketujuh lapis langit yang diliputi belaian karunia lembut penuh keakraban yang datang dari hadirat Ilahi, memiliki kehormatan yang dikhususkan oleh 
Allah, manusia dengan kedudukan terhormat di sisi Allah dengan derajat yang tinggi di sisi Allah, keluarga dan sahabatnya mencapai puncak derajat yang tinggi karena dekat kepadanya, dan makhluk tertinggi dan terluas kedudukannya.

\subsection{Model Kesempurnaan Fisik}

Penampilannya mencengangkan akal dan pikiran, merupakan sebuah keajaiban, memiliki rupa elok bagaikan bulan purnama, berperawakan sedang, warna kulitnya putih kemerah-merahan, dahinya lebar serasi, panjang rambutnya sampai batas telinga, kedua lengan dan kaki serta persendian semuanya dalam bentuk ukuran sempurna, mantap dalam seluruh keindahan serta keserasian sifat-sifatnya, penglihatan, pendengaran, atau ucapannya tidak dapat disamakan, ciptaan Allah dengan bentuk terbaik, segala keindahan terangkum dan terkhususkan, wajahnya cerah secerah taman yang menyegarkan, bentuk tubuhnya sempurna.

\subsection{Model Penolong}

Mutiara amat berharga, pertolongan Allah selalu mendampinginya, memberikan manfaat dan syafa'at kepada umatnya, seorang Rosul, wasilah kepada Allah, pemberi syafa'at, penolong dengan pertolongan yang kuat, makhluk pembawa rahmat Tuhan, dan mempermudah yang sulit.

\subsection{Model Kebahagiaan}

Pembawa kegembiraan yang riang dan bergelimang dan pembawa berita gembira. Berita gembira yang dibawa Nabi Muhammad tidak hanya mengenalkan Islam dan Allah kepada umatNya, namun juga memberikan kabar bahwa dengan berkah Nabi Muhammad mereka mendapatkan banyak keistimewaan dari Allah, salah satunya dikabulkannya doa dengan wasilah Nabi Muhammad.

\section{Mengapa Nabi Muhammad Dijadikan Wasilah dalam Berdoa?}

Setiap tindakan manusia selalu berdasarkan konsep atau pengetahuan yang melatarbelakanginya. Termasuk dalam tindakan berdoa. Seperti yang telah diketahui bahwa sebagaian besar umat Islam dalam berdoa memperhatikan beberapa adab dalam berdoa, seperti bertawasul dengan nama Nabi Muhammad yang diaplikasikan melalui bacaan salawat. Maka, tidak heran jika seyogyanya umat Islam selalu mengawali doanya dengan bacaan tahmid dan salawat. Para umat Islam percaya bahwa dengan berkah bacaan salawat kepada Nabi Muhammad akan menjadi perantara terkabulnya doa. Hal ini dikarenkan banyaknya keberkahan yang dibawa atas nama Nabi Muhammad. Ternyata, fenomena kebahasaan yang sering kali dijumpai ini juga dapat diijelaskan secara Ilmiah, yaitu dalam kajian Lingustk Kognitif. Setiap tindakan manusia selalu didasarkan atas konsep tertentu. Mengapa Nabi Muhammad yang dijadikan wasilah? Tentu saja ada prototipe dan model yang diidealkan oleh umat Islam menurut syariat Islam salah satunya dalam Kitab terjemahan Simtudduror.

Nabi Muhammad dijadikan wasilah dalam berdoa karena beberapa alasan sebagai berikut. Di sisi Allah, NABI MUHAMMAD merupakan insan paling utama, mulia, sempurna, kekasih Allah, memiliki kedudukan tertinggi, dianugerahkan fisik paling sempurna, sebagai penolong terbaik, dan pembawa kebahagiaan bagi umat manusia. Dengan 
prototipe NABI MUHAMMAD tersebut mendorong umat Islam untuk memanfaat keberkahan dari tingginya derajat yang diberikan oleh untuknya. Lebih dari itu, manusia khususnya umat Islam memiliki kesepakatan bersama tentang kategori-kategori yang mencirikan NABI MUHAMMAD. Hal ini dapat diteliti dengan menggunakan model kognitif ideal. Dari model ini dapat diketahui bagaimana sekelompok masyarakat tertentu mengidealkan entitas tertentu. Bagiamana idealnya seseorang atau makhluk Allah dapat dijadikan wasilah dalam berdoa dilihat dari beberapa model, yaitu MODEL PENGUTAMAAN, KEMULIAAN, KESEMPURNAAN, KEKASIH, KEDUDUKAN TERTINGGI, KESEMPURNAAN FISIK, PENOLONG, dan KEBAHAGIAAN.

Semua model NABI MUHAMMAD yang diidealkan di atas tentu saja tidak ada persamaannya dengan makhluk yang lain ataupun dengan bangsa manusia, sebagai golongan makhluk yang sama dengan Nabi Muhammad. Diagram di bawah ini diharapkan dapat mempermudah untuk memahami bagaimana umat Islam mengidealkan sosok NABI MUHAMMAD sehingga dapat dijadikan wasilah dalam berdoa.

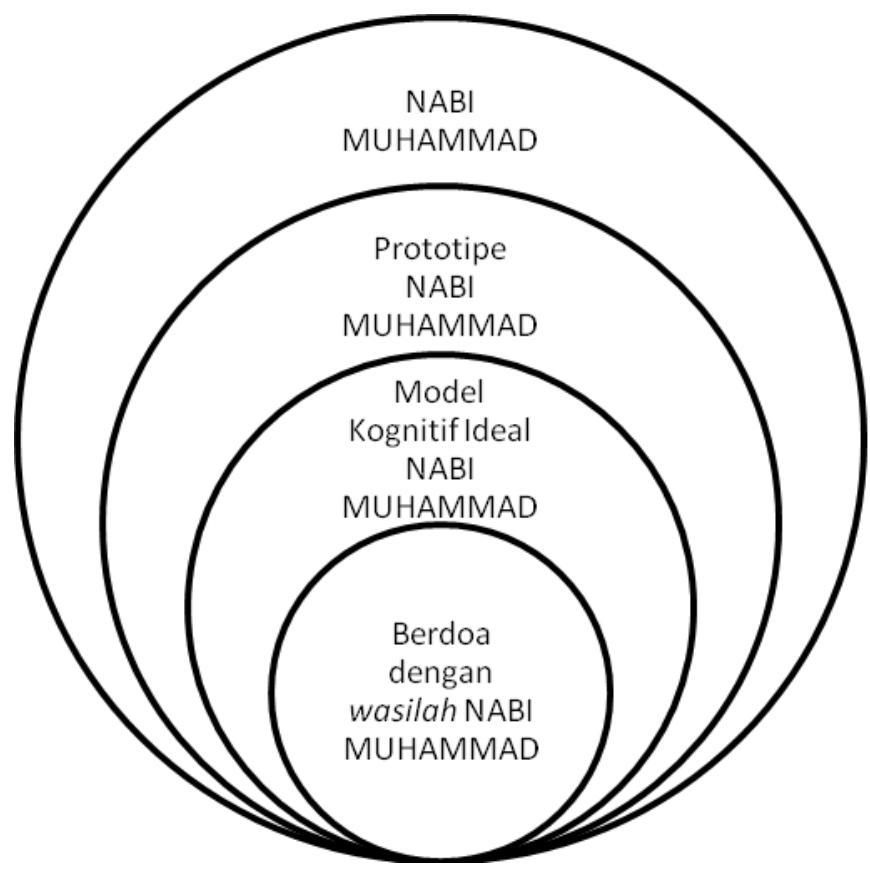

Gambar 1. Hubungan Prototipe Dan Model Kognitif Ideal Nabi Muhammad

Atribut-atribut yang melekat pada diri Nabi Muhammad dapat dikatakan istimewa dibandingkan dengan yang dimiliki oleh manusia pada umumnya. Atribut tersebut mendukung kehadiran Nabi Muhammad yang memiliki nilai istimewa bagi Allah, sehingga berkah dari kehadirannya dapat dijadikan perantara terkabulnya doa seorang hamba. Di sinilah dapat dilihat adanya konsep hubungan seorang Nabi dengan Tuhannya yang memiliki pengaruh terhadap makhluk lainnya, misalnya manusia. Konsep hubungan antara makhluk, salah satunya alam dengan Tuhannya telah digambarkan oleh Schroeder (2005). Dari bagan konsep ICM ALAM yang dibuat oleh Schroeder dapat juga disesuaikan untuk menunjukkan hubungan Allah, Nabi Muhammad, dan dikabulkannya doa umat Nabi Muhammad sebagai berikut. 


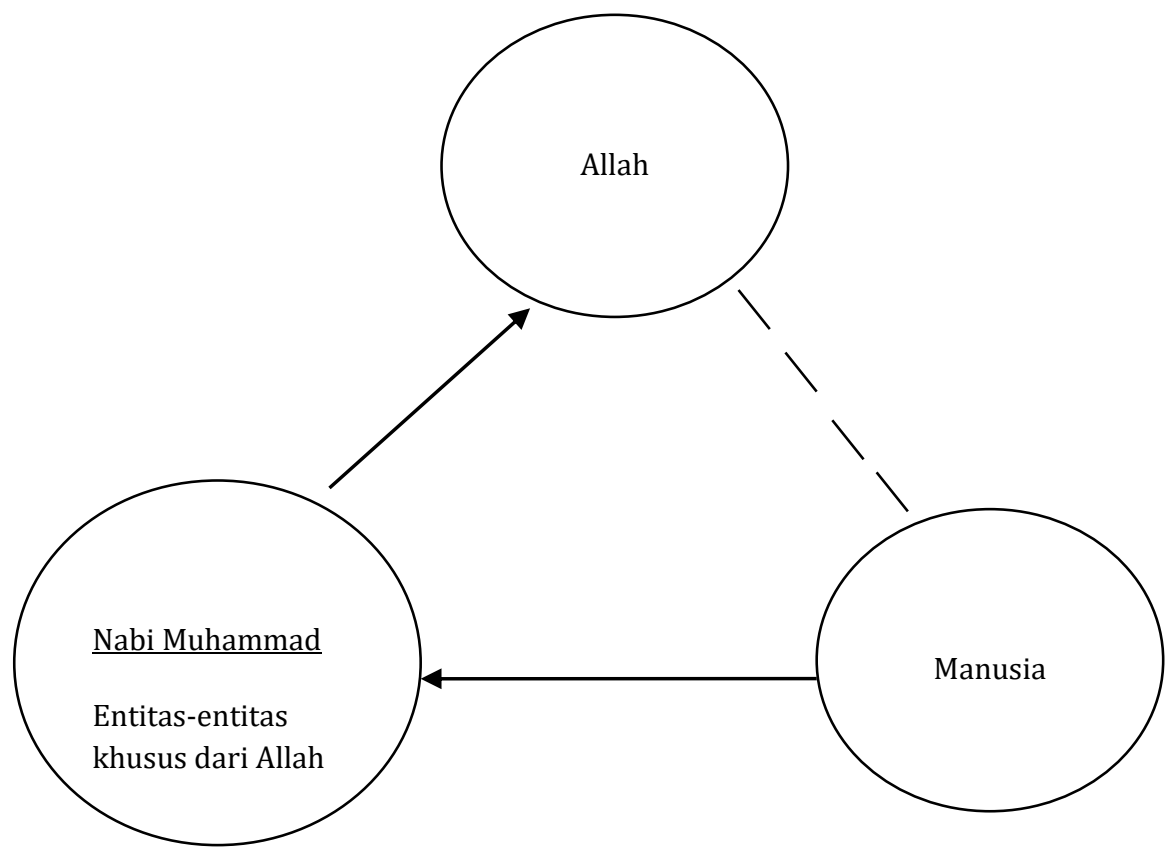

Gambar 2. Konsep ICM hubungan Tuhan, Nabi Muhammad, dan Manusia

Dari gambar 2 dapat dilihat bahwa konsep hubungan Nabi dan Tuhannya memiliki pengaruh terhadap makhluk lainnya, dalam hal ini adalah manusia. Umat manusia patuh terhadap nilai-nilai yang diajarkan Nabi memudahkan manusia memahami wasilah-nya.

\section{SIMPULAN}

Nabi Muhammad sudah sepantasnya dijadikan wasilah dalam berdoa. Apalagi setelah diketaui faktor-faktor yang mendukung pernyataan tersebut. Dengan menggunakan perangkat anaisis Linguistik Kognitif - prototipe dan model kognitif ideal (ICM) dapat diketahui bagaimana umat dan syariat Islam mengidealkan seorang figur yang dapat dijadikan perantara terkabulnya doa umat Islam. Protipe-protoitpe NABI MUHAMMAD yang diidealkan oleh agama dan umat Islam menunjukkan adanya beberapa keistimewaan NABI MUHAMMAD yang digambarkan dengan model-model kognitif ideal. Model-model yang diidealkan tersebut meliputi MODEL PENGUTAMAAN, KEMULIAAN, KESEMPURNAAN, KEKASIH, KEDUDUKAN TERTINGGI, KESEMPURNAAN FISIK, PENOLONG, dan KEBAHAGIAAN. Dengan memanfaatkan berkah dari keistimewaan NABI MUHAMMAD di mata Allah lah sebagaimana diidealkan dalam model-model tersebut, maka Nabi Muhammad dijadikan wasilah dalm berdoa.

Diharapkan dengan adanya artikel ini dpaat membuka jalan bagi peneliti lain untuk dapat lebih mengeksplor studi Linguistik Kognitif pada ranah keagamaan mengingat kurangnya studi yang mempelajarinya. Sehingga salah satu cabang linguistik terapan ini dapat mencakup segala aspek kehidupan. 


\section{REFERENSI}

Abdullah, I. H. \& Hashim, R. S. (2016). A Cognitive semantic analysis of Alam (nature) in Malay. European Journal of Social Science 8 (1), 140-151.

Al-Habsyi, A. (2019). Maulid Nabi Muhammad SAW: Simtudduror Terjemahannya.diunduh dari cehuigraphics.com.

Arimi, S. (2009). Ihwal metode penelitian sosiolinguistik. Yogyakarta: Fakultas Ilmu Budaya UGM.

Arimi, S. (2015). Linguistik kognitif: sebuah pengantar. Yogyakarta: A.Com Advertising

Evans, V.\& Green, M. (2006). Cognitive linguistics: an introduction. Edinburgh:Edinburgh University Press.

https://www.ahlulbaitindonesia.or.id/berita/index.php/s13-berita/mengenal-sosoknabi-muhammad-saw-melalui-ayat-suci-alquran/. Diakses Selasa, 25 Juni 2019.

https://konsultasisyariah.com/8105-doa-dengan-shalawat.html. Diakses pada Senin, 10 Februari 2020.

https://quran.kemenag.go.id. Diakses pada Rabu, 12 Februari 2020.

https://konsultasisyariah.com/8105-doa-dengan-shalawat.html. Diakses Selasa, 25 Juni 2019.

Lakoff, G. (1987). Women, fire, and dangerous things. Chicago and London: The University of Chicago Press.

Peels, R. (2011). Sin and human cognition of God. Scottish Journal of Theology Ltd 4, 390409. doi:10.1017/S0036930611000214.

Rosch, E. (1978). Principles of categorization. In Rosch, E., Lloyd, \& Barbara, B. (Eds). Cognition and Categorization (pp. 27-48). Hillsdale, NJ: LawrenceErlbaum.

Schroeder, H. (2005). The meaning of 'nature': Insight from cognitive linguistics, In Paden, J. G. \& Schuster, R. M. (Eds). Proceedings of the 2005 northeastern recreation research symposium; 2005 April 10-12; Bolton Landing, NY. Gen. Tech. Rep. NE-341. Newtown Square, PA: U.S. Forest Sevice, Norteastern Research Situation.

Sudaryanto. (1988). Metode linguistik bagian kedua: metode dan teknik pengumpulan data. Yogyakarta: Gadjah Mada University Press.

Sudaryanto. (2015). Metode dan aneka teknik anlisis bahasa: pengantar penelitian wahana kebudayaan secara linguistis. Yogyakarta: Sanata Dharma University Press.

Varela, F., Thompson, E., \& Rosch, E. (1991). The embodied mind. London: The MIT Press. 